\title{
ИНФОРМАЦИОННЫЕ СИСТЕМЫ В СТРОИТЕЛЬСТВЕ
}

УДК 624.014.2

\section{А.А. Волков, А.А. Василькин \\ ФГБОУ ВПО «МГСУ» \\ РАЗВИТИЕ МЕТОДОЛОГИИ \\ ПОИСКА ПРОЕКТНОГО \\ РЕШЕНИЯ \\ ПРИ ПРОЕКТИРОВАНИИ \\ СТРОИТЕЛЬНЫХ \\ МЕТАЛЛОКОНСТРУКЦИЙ ${ }^{1}$}

Даны оценки существующих подходов к поиску проектных решений стальных строительных конструкций, указаны особенности типового и индивидуального проектирования. Предложен ассоциативный метод выбора проектного решения, когда процесс поиска направляется таким образом, чтобы получить выгодное совпадение проектных ситуаций, настоящей и ранее реализованной, и применить апробированные решения. Для рассмотрения максимально возможного количества комбинаций проектного решения строительных конструкций предложено построение дерева перебора вариантов возможных решений, при котором варьируются возможные значения параметров решения. Показан алгоритм поиска проектного решения. Описаны три уровня решения задачи проектирования стальных строительных конструкций. Дан анализ и оценка эфффективности дополнительных затрат на построение полного дерева перебора вариантов.

Ключевые слова: проектное решение, автоматизированное проектирование, стальные конструкции, ассоциативный метод, эффективность, выбор, оптимальное решение.

1 Работа выполнена в рамках Гранта государственной поддержки научных исследований, проводимых ведущими научными школами Российской Федерации № 14.Z57.14.6545-НШ.
A.A. Volkov, A.A. Vasil'kin

$M G S U$

DEVELOPMENT

OF THE METHODOLOGY

OF THE DESIGN DECISION SEARCHING IN THE PROCESS OF STRUCTURAL METALWORK DESIGN ${ }^{1}$

The design decision is usually a synthesis of various requirements to the construction object. The main difficulty is to approve the solution results of all the subtasks, because these various requirements often contradict each other.

In the article the existing approaches to design solutions searching for steel structural designs are considered, features of standard and individual design are specified. The associative method of choosing the design decision is offered. The process of search is directed in order to receive favorable coincidence of design situations, current and implemented earlier and to apply the approved decisions.

In order to consider the greatest possible quantity of combinations of design solution for structural designs in the article it is offered to create a tree of enumeration of possibilities for decisions, in case of which the possible values of decision parameters vary. The algorithm of searching the design decision is shown by a method of a tree of search creation. Three levels of solution for a problem of steel structural designs are thus described.

Also the question is raised of the effectiveness of padding expenses for creating the complete tree of search of options, their analysis and assessment.

Key words: design decision, computer design, steel structures, association method, efficiency, choice, optimal decision.

1 The work is written in frames of State support Grant for Scientific Incestigations carried out by the leading schools of the Russian Federation no. 14.Z57.14.6545-NSh. 
На современном уровне развития науки и техники объекты проектирования имеют высокую сложность, а в процессе их создания участвуют специалисты многих специальностей: руководители проекта, логисты, экономисты, программисты и проектировщики-профессионалы архитекторы, конструкторы, технологи и т.д. Все участвующие в проектировании имеют свое представление об объекте, решают свою конкретную подзадачу и выдвигают определенные требования к его проектированию, возведению и эксплуатации. В результате этого проектное решение представляет собой синтез разнородных требований к строительному объекту [1]. Основная трудность состоит в согласовании результатов решений всех подзадач, поскольку эти разнородные требования часто бывают противоречивыми.

Возрастающая стоимость строительных объектов обусловливает необходимость проводить многовариантную и комплексную проработку проектного решения. Но, как отмечают специалисты, «этому мешает... отсутствие в нормативных документах формализованных правил получения эффективных проектных решений» [2]. Несмотря на имеющийся опыт принятия проектных решений и немалое количество публикаций по этому вопросу [3-5], по-прежнему остается актуальной проблема развития и совершенствования общих методов поиска проектного решения сложных строительных объектов с несущими стальными конструкциями.

Дж. Диксон отмечает, что, в значительной мере, качество решения определяется качеством идеи использованной на данном этапе [6]. В определенном смысле этап выбора проектного решения представляет собой основу проектирования, на котором закладывается экономическая эффективность строительного сооружения.
On the contemporary stage of science and technology development the design objects are of high complexity and in the process of their creation experts of different qualification take part: project supervisors, logisticians, economists, programmers and designers-specialists - architects, structural designers, technologists, etc. All the people taking part in the design have their own idea of the object, solve their special subtasks and pose their certain requirements to its design, erection and operation. As a result, the design solution is a synthesis of various requirements to the construction object [1]. The main difficulty is in the process of approving the results of all the subtasks, because these different requirements are often controversial.

The growing cost of construction objects is reasoning in the necessity to conduct multiversion complex study of the design solution. But, as specialists note, "the absence of formalized rules for getting efficient design solutions in normative documents stands in the way" [2]. Despite the existing experience of making design decisions and considerable amount of publications on this issue [3 - 5] the problem of the development and advancement of the general search methods of design solution search for complicated construction objects with bearing steel structures still stays current.

J. Dickson notes that the quality of the solution is mostly determined by the quality of the idea applied at the given stage [6]. In some sense the stage of design solution choice is a basis of design, which determines the economic efficiency of the building structure. 
Проектирование зданий и сооружений, а именно поиск и принятие оптимального проектного решения, - сложная задача, которую можно решить путем перебора и комбинации переменных параметров. Специалисты указывают, что для создания одного удачного изделия требуется 55..60 идей [7]. Аналогично мы можем сказать, что для получения оптимальной конструкции строительного сооружения необходимо рассмотреть значительное количество вариантов конструкции - проектных решений.

Теоретически этот перебор является конечным, однако количество вариантов перебора может быть столь велико, что для получения оптимального решения понадобиться затратить значительные ресурсы на их проработку, и стоимость получения оптимального варианта проектного решения существенно возрастет.

Учитывая значительный объем информации при проектировании стальных конструкций, многочисленные параметры, которые являются переменными, ручное составление и анализ всех комбинаций проектного решения, задача принятия оптимального решения является достаточно трудоемким делом. В этих условиях на первый план выходят средства автоматизированного проектирования и, в частности, автоматизированного перебора и оценки вариантов проектного решения.

На практике, когда проектировщик решает задачу по проектированию какоголибо сооружения, он использует не только свои знания в области строительства, но и исторически накопленный строительный опыт, что способствует экономии ресурсов, более быстрому и глубокому решению задачи, а также снижает риск появления ошибок.

Задача поиска проектного решения при проектировании стальных конструкций начинается с того, что необходимо рассмотреть максимально возможное ко-
The design of buildings and structures, which means searching and making the optimal design decision, is a complicated task, which may be exactly solved by exhaustion and combination of variable parameters. The specialists note, that in order to create one good product one needs 55...60 ideas [7]. In analogue we can say, that in order to get the optimal construction of a building structure one needs to consider a substantial amount of construction variants — design solutions.

Theoretically this exhaustion is finite, though the number of variants can be so great, that in order to get the optimal solution one needs to spend much resources for working them out and the cost of getting the optimal solution will substantially increase.

Taking into account the considerable volume of information in the process of steel structures design, numerous parameters, which are variable, as well as manual compilation and analysis of all the combinations of the design solution, the task of making optimal decision is rather labour-consuming. In such conditions the means of automated design are on the foreground, which includes automated compilation and analysis of the variants of design solution.

In practice, when a designer solves a design task for some construction, he or she applies not only own knowledge in the field of construction, but also the gathered construction experience, which provides resource saving, faster and deeper task solution and also reduces the risk of mistakes.

The task of design solution search in case of steel structures 
личество комбинаций проектного решения, после чего с помощью оценочной функции определяется оптимальный вариант.

В настоящей статье подробно рассмотрены методы формирования вариантов проектного решения. Данная задача может быть решена с помощью формирования дерева перебора возможностей (рис. 1). design is beginning with consideration of maximum possible amount of design solution combinations, after that the optimal variant should be determined using valuation function.

In the given article the methods of design solution variants formation are considered. The given task may be solved using variants search tree (fig. 1).

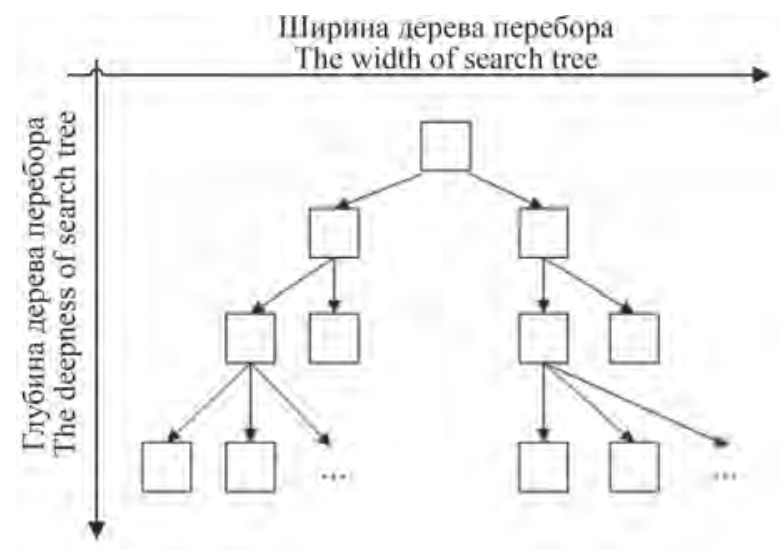

Рис. 1. Дерево перебора вариантов

Общий подход к проектированию строительных конструкций может выражаться двумя основными направлениями - уникальное проектирование и типовое проектирование. Под проектированием уникального объекта понимается объект строительства, выполненный по индивидуальному проекту. Это может быть уникальное сооружение, которое либо ранее вообще не строилось, либо имеет несколько аналогов по всему миру. К подобным объектам можно отнести здания с индивидуальной архитектурой, стадионы, большепролетные конструкции и т.д. Для получения оптимального проектного решения таких сооружений необходимо выполнить полный перебор переменных параметров проектного решения конструкции - класса стали, профиля элемента, типа кон-
Fig. 1. Variants search tree

The general approach to the design of building structures may be expressed by two main directions - unique design and typical design. Unique object design shall be understood to be a construction object produced according to special design. It can be a unique structure, which has never been constructed yet or has only several analogues over the world. Such objects include, for example, buildings with individual architecture, stadiums, large-span structures, etc. In order to get optimal design solution for such structures it is necessary to carry out exhaustive enumeration of variable parameters of a structure design solution - steel grade, element profile, construction type, etc. As a result of it a big search tree can be compiled. Of course, some additional restrictions may exist — architectural, technologi- 
струкции и т.д., в результате чего может быть построено большое дерево перебора. Разумеется, при этом могут существовать дополнительные ограничения - архитектурные, технологические, функциональные, определяющие внешний вид и особенность конструкций.

Противоположный тип проектирования - типовое, которое активно внедрялось и использовалось в отечественном строительстве. Типовое проектирование зданий и сооружений предназначено для многократного применения в строительстве, поскольку большинство типов зданий в СССР имело многократную повторяемость. Типовые проекты разрабатывались в течение длительного времени ведущими проектными институтами страны, многократно проверялись и оптимизировались. Затем по утвержденным проектам возводилось несколько экспериментальных зданий, которые эксплуатировались и наблюдались на протяжении длительного срока иногда до 10 лет. Если при эксплуатации здания или сооружения не возникало отказов, аварий, предельных состояний, то типовой проект данного сооружения запускался в массовое серийное строительство. При проектировании по типовому проекту происходит так называемая «привязка» типового проекта. В зависимости от гидрогеологических условий района строительства, снеговой и ветровой нагрузки в проекте могут изменяться сечения несущих элементов конструкции. Основные же объемно-планировочные и конструктивные решения остаются неизменными. Соответственно, для зданий и сооружений из стальных несущих конструкций, проектируемых по типовому проекту, дерево перебора вариантов будет минимальным. cal, functional, determining appearance and features of the constructions.

The opposite design type is typical, which has been actively implemented and used in native construction. Typical design of buildings and structures is oriented at multiple application in construction, because most types of buildings in the USSR were repeatedly reproduced. The typical designs have been developed during long period of time by the leading design institutes of the country, they have been multiply checked and optimized. After that several experimental buildings were erected according to the approved projects, which have been operating and examined during long period of time, sometimes up to 10 years. If in the process of operation there were no failures, accidents, limit states, the typical design of the building entered into mass construction. In case of design according to typical project the so-called "binding" of typical design takes place. Depending on hydrogeological conditions of the construction area, snow and winter impact, changes in the cross-section of the bearing elements can occur in the project. But the main spatial and constructive solutions stay unchanged. That means, the search tree will be minimal for buildings and structures made of steel bearing constructions designed according to typical project.

The known American scholar P. Hill points out, that the development of ideas can give the maximal effect when creative imagination addresses other ideas and one idea appears on the basis of another [7]. Consequently, it is possible to offer associative design method, which will represent the third, intermediate design variant and will take its place between typical and individual design. The idea of the method 
Известный американский ученый П. Хилл указывает, что разработка идей может дать наибольший эффект, когда творческое воображение обращается к другим идеям, и одна идея возникает на основе другой [7]. Соответственно, можно предложить ассоциативный метод проектирования, который будет представлять собой третий, промежуточный, вариант проектирования, и занимать место между типовым и индивидуальным проектированием. Идея метода заключается в том, что проектировщик, решая какую-либо неточную задачу, при возникновении ситуации, напоминающей ему уже происходившую ранее, использует опыт прошлого. Частичное совпадение с ситуацией в данном случае может дать ключ к более простому принятию решения, поскольку при составлении дерева перебора вариантов необходимо составлять только часть дерева перебора. Такую последовательность действий можно отнести к методу ассоциаций.

Применительно к проектированию строительных объектов алгоритм будет следующий. В прошлом, при решении похожей задачи, проектировщик уже принял проектное решение. В настоящее время необходимо убедиться будет ли оптимальным примененное в прошлый раз решение. Если да, то в данной точке дерева проектного решения поиск решения заканчивается. С помощью ассоциаций с ранее использованными решениями определяется направление перебора вариантов. Частичное формирование дерева перебора позволяет экономить ресурсы, которые можно использовать в поиске решения в оригинальной ситуации в дальнейшем.

В этой связи можно предложить следующий вариант решения задачи поиска проектного решения, который заключается в том, что при выполнении проекта необходимо стремиться получить выгодное совпадение проектных ситуаций - использовать такие типовые узлы, элементы is that the designer applies the past experience when solving some inexact task in case a situation happens reminding him the situation, which has happened before. The partial coincidence with the situation in this case can give clue to easier solution, because while compiling the search tree one needs to compile only a part of it. Such sequence of actions may be attributable to association method.

Relating construction objects design the algorithm will be as follows. In the past, in case of solving similar problem, the designer has already made design decision. At the present time it is necessary to make sure that the solution made before will be still optimal. If yes, in this point of the tree the search of design solution ends. With the help of associations with the solutions used before the direction of enumerating possibilities is defined. The partial formation of search tree allows saving resources, which can be used in searching the solution in a unique situation in the future.

In this regard the next variant of searching the design solution may be offered, which supposes, that in case of project implementation it is necessary to try to get beneficial coincidence of design situations - to use such typical junctions, elements and constructions, the efficiency of which is already proved and tested.

If the construction took place in the past, estimation of its decision is also known. Of course, in this case there can be variants when the decision made before was shallow, without the full enu- 
и конструкции, эффективность использования которых уже подтверждена и апробирована.

Если конструкция встречалась в прошлом, то оценка ее решения также известна. Разумеется, в данном случае могут быть варианты, когда ранее принятое решение было сделано поверхностно, без полного перебора и оценки вариантов проектного решения. Другим осложняющим фактором может быть то, что в прошлом проектировщик использовал определенный критерий оптимальности для оценки и выбора проектного решения. А в сегодняшней ситуации для заказчика проекта могут быть более актуальны другие критерии - например, сроки возведения конструкции и сдачи объекта в эксплуатацию или применение только определенного типа профиля.

Итак, можно выделить три типа поиска проектного решения. Первый - в уникальных проектах, когда опыт проектирования помочь не может, необходимо формировать варианты проектных решений и строить полное дерево перебора вариантов. Второй - когда проектная ситуация частично (техническое задание, условия эксплуатации, функциональное назначение, район строительства) уже встречалась ранее. В таком случае известно дальнейшее формирование части дерева перебора. Если это позволяет получить оптимальное проектное решение, то дальнейшее формирование дерева перебора можно прекратить, что позволяет экономить время и ресурсы. При применении этого метода поиска решения необходимо частичное формирование дерева перебора. И третий тип поиска - когда происходит полное совпадение ситуации в данном проекте и выполненном ранее, например, использование типового проекта. При этом оценка вариантов становится известной без дополнительных затрат ресурсов. В своей практической деятельности при разработ- meration and estimation of design solution variants. There may be another complicating factor - in the past the designer used some definite optimality criterion for estimating a design solution. And in the current situation some other criteria may be important for the customer, for example, terms of building the construction and its completion or use of only one type of profile.

Thus, three types of design decision search may be detached. The first concerns unique projects, where the design experience can't help. Then it's necessary to develop the variants of design solutions and compile the full search tree. The second type is when the design situation has already partly happened (technical specification, operation conditions, functional purpose, construction area). In this case the further development of the search tree is known. If it helps to obtain optimal design solution, it is possible to stop the further development of the tree, which allows saving time and resources. In case of using this decision search method the partial compilation of search tree is necessary. And the third search type is when the situations in the current project and in the past project fully coincide, for example in case of typical design use. In this case the estimation of variants becomes known without additional resources. A designer most often uses all the three methods in his or her practical activity in the process of construction design development.

We believe, that in order to implement the automated design 
ке проекта объекта строительства проектировщик чаще всего применяет все три метода поиска решения.

Нам представляется, что для реализации автоматизированного проектирования программный комплекс должен реализовать все три указанных метода, т.е. решать задачу путем перебора переменных параметров, а также иметь библиотеку типовых и ранее использованных проектных решений, чтобы компьютер мог уменьшить дерево перебора путем подставки «знакомого» решения в одну из ветвей. При совпадении программы для выбора проектного решения системе автоматизированного проектирования следует передать специальные знания в области строительного проектирования, чтобы эти знания можно было использовать при ассоциативном и справочном методе поиска решения.

Для решения этой задачи с применением вычислительной техники необходимо формализовать задачу.

Математически процедура перебора исследует вариант за вариантом. Ситуация однокритериального принятия решения описывается следующей моделью - существуют альтернативы $x_{k}, k=1, \ldots, n$, которые образуют множество решений $X=\left\{x_{1}, \ldots, x_{n}\right\}$, одно из которых является оптимальным.

При этом дерево перебора формируется в полном объеме, что может вызывать значительный расход ресурсов вычислительного устройства при решении задачи большой размерности.

Рассмотрим процесс поиска проектного решения, реализованного путем перебора вариантов в оригинальной ситуации перебора, для уникальных зданий (рис. 2).

При проектировании уникального строительного объекта, выполненного по индивидуальному проекту, возникает оригинальная ситуация перебора. Теоретически этот перебор является конечным, однако получение оптимального engineering, software should implement all the three methods, which means to solve the task by enumerating variable parameters and also to possess a library of typical and already used design solutions, so that the computer could minimize the search tree by means of substituting the "familiar" solution into one of the branches. In case of program coincidence, one should pass the special knowledge in the field of construction design to automated design system in order to use this knowledge in associative and informative solution search method.

In order to solve this task with the use of computer techniques it is necessary to formalize the task.

The mathematical procedure of enumeration is researching variant after variant. The situation of one criterion decision making is described by the following model - there exist alternatives $x_{k}$, $k=1, \ldots, n$, which constitute a set of decisions $X=\left\{x_{1}, \ldots, x_{n}\right\}$, one of which is optimal.

At that the search tree is formed fully, which can give rise to great resource consumption of computer mechanism in case of solving a task of high dimension.

Let's regard the process of searching the design solution, implemented by variants enumeration in unique enumeration situation, for unique buildings (fig. 2).

In the process of designing a unique construction object according to a unique project an original enumeration situation occurs. Theoretically this enu- 
решения затруднено, поскольку количество вариантов перебора столь велико, что понадобится затратить значительные ресурсы на их проработку, и от этого стоимость получения оптимального варианта проектного решения значительно возрастет. meration is finite, though getting optimal solution is complicated, because there are so many variants, that great resources are needed for their study, and the cost of getting optimal variant increases greatly.

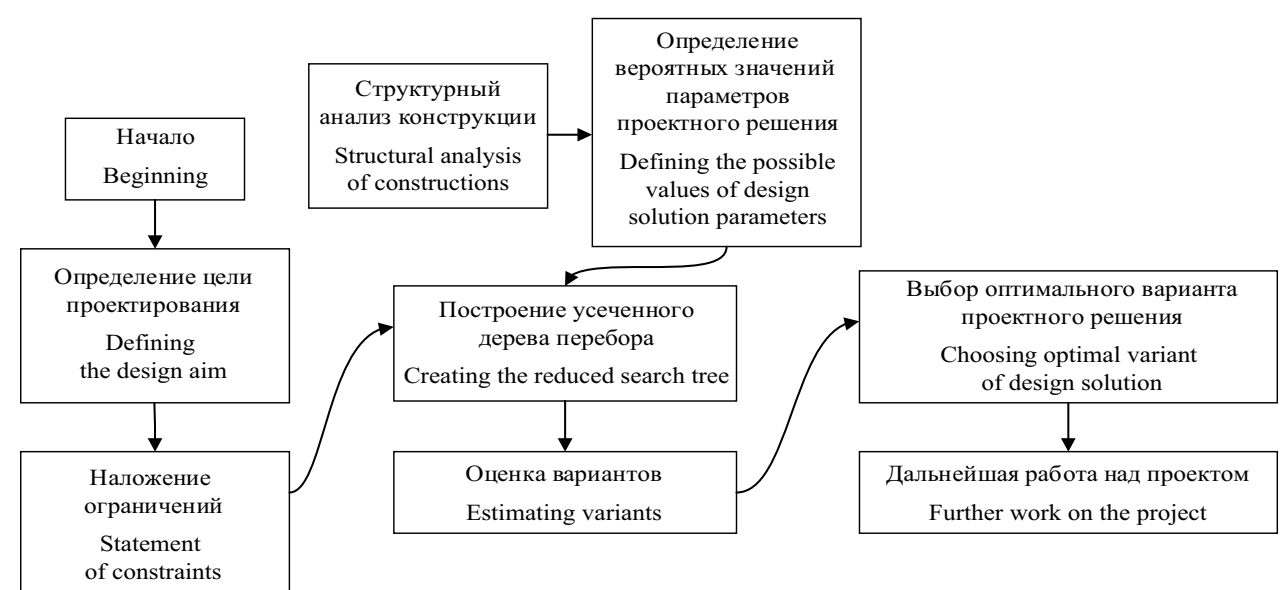

Рис. 2. Этапы поиска проектного решения методом построения дерева перебора

Процесс формирования дерева перебора целесообразно начать с определения цели перебора вариантов. В качестве цели проектирования мы примем составление проектного решения конструкции или элемента конструкции путем комбинации переменных параметров, характеризующих конструкцию так, чтобы целевая функция по заданному критерию оптимальности и установленным ограничениям была минимальна (максимальна).

В связи с этим авторами предлагается использовать усечения дерева перебора вариантов проектного решения в целях ограничения времени решения, в результате чего процесс проектирования становится неточной задачей. Подобный подход к решению переборных задач предложил чемпион мира по шахматам M.M. Ботвинник, использовавший этот метод при разработке шахматной программы [8].

Fig. 2. Steps of design solution search by search tree method

It is reasonable to begin the process of search tree creation with determining the aim of enumeration. Let us admit that the aim of design is creating the design solution of the construction or an element of a construction by combining variable parameters characterizing the construction so that the purpose function according to the specified optimality criterion and the given constraints would be minimal (maximal).

In this regard the authors suggest using the search tree reduction in order to reduce the time for solution. As a result, the design process becomes a rough task. Such an approach to solving search problems was suggested by the world champion in chess M.M. Botvinnik, who used this method in the process of developing a chess program [8]. 
Решая неточную задачу, необходимо установить «неточную» - промежуточную цель, поскольку ставить перед собой общую цель задачи будет неоправданно. В качестве промежуточной цели примем формирование проектного решения конструкции, удовлетворяющее ограничениям - условиям прочности и жесткости, транспортабельности, технологичности и т.д.

Для упрощения и ускорения решения задачи по перебору вариантов целесообразно использовать существующий опыт проектирования стальных конструкций и наложить некоторые ограничения.

Ограничением задачи будет ограничение предельной длины варианта. Идея заключается в том, что вместо процедуры формирования максимального количества комбинаций проектного решения необходимо выделить неконструктивные и заведомо неэффективные комбинации переменных проектного решения. Например, нецелесообразно рассматривать в переборе вариантов проектного решения одноэтажного промышленного здания со стальным каркасом стропильную ферму с треугольным очертанием поясов и жестким закреплением к колонне, поскольку конструктивно треугольная ферма не может передать опорный момент через «острый» опорный узел и фактически будет работать шарнирно. Отобранные варианты формируют дерево перебора.

Вторым, не менее важным этапом после построения дерева, будет процедура оценки вариантов, поскольку необходимо найти оптимальный вариант. Оценка проектных решений представляет собой отдельную задачу, широко представленную в [9-11]. Каждый вариант дерева перебора оценивается с помощью целевой функции и критерия оптимальности.

После проведения оценки вариантов, проектировщик отбирает оптимальный вариант проектного решения [12].
While solving this problem it is necessary to set a "rough" intermediate goal, because it would be unreasonable to set the general aim of the task. As an intermediate goal let us admit design solution formation for a construction, which satisfies the restrictions — the conditions of durability and rigidity, transportability, fabricability, etc.

It order to make the search solution easier and faster it is reasonable to use the existing experience of steel structures design and set some restrictions.

Restricting the critical length of the variant will be the restriction of the task. The idea is in the fact that instead of creating maximal quantity of combinations of design solution it is necessary to detach non-constructive, obviously unefficient combinations of the design solution variables. For example, it is unreasonable to investigate truss with $\mathrm{V}$-shaped booms and rigid fixing on a column in casdesign e of variants ennumeration for one-storeyed industrial building with steel framework, because V-shaped truss can't deliver the moment at support through a "sharp" heel joint and will practically operate pivotally. The selected variants create the search tree.

The second stage after creating the search tree is not of less importance - it is the procedure of estimating the variants, because it is necessary to choose the optimal variant. Estimating design decisions is a separate task, which has been widely presented in [9-11]. Each variant of the search tree is estimated with the help of aim function and optimality criterion. 
Проработка этапов поиска проектного решения предполагает последовательное развитие стадий аналитического процесса через дерево перебора возможностей. В процессе проектирования стальных строительных конструкций можно выделить три стадии или уровня задачи проектирования.

Первым уровнем является проектирование элементов, образующих стальную конструкцию. Например, проектирование элемента «балка» в балочной клетке. Данный уровень имеет конкретную цель - необходимо определить материал элемента, линейные размеры и поперечное сечение при проверке нормальных $\sigma_{n}$, касательных $\tau_{x y}$, локальных $\sigma_{\text {lос }}$ и эквивалентных напряжений $\sigma_{n p}$, прогиба $f$, общей и местной устойчивости.

Вторым уровнем будет проектирование системы элементов, конструктивно связанных и передающих друг на друга нагрузки элементов. Например, в балочной клетке от вида колонны зависит конструкция опорного ребра балки, а от способа опирания балки — конструкция оголовка колонны.

И третий уровень задачи рассматривает работу всего сооружения в целом совокупность всех элементов первого уровня, составляющих конструкцию, и общие факторы, оказывающие влияние на работу элементов первого уровня, такие как расчетная схема сооружения, учет пространственной работы здания, ограждающие конструкции, инженерные сети объекта строительства и т.д.

Затратьл на проектирование. Рассмотрим вопрос дополнительных затрат на проектирование, которые будут возникать в результате поиска оптимального проектного решения, синтеза и оценки вариантов, учета многокритериальности, рисков, неопределенности задачи проектирования и других усложняющих решение факторов.
After estimating the variants, the designer is choosing the optimal variant of the design solution [12].

Working out the design solution search stages supposes a stepby-step development of analytical process stages with the help of the search tree of possibilities. In the process of steel structures design it is possible to detach three stages or three levels of the design task.

The first level is design of the elements, which firm the steel structure. For example, the design of the element "beam" in a beam system. This level has its specific aim - it is necessary to define the element's material, linear dimensions and crosssection in the process of checking normal $\sigma_{n}$, tangent $\tau_{x y}$, local $\sigma_{l o c}$ and equivalent strains $\sigma_{n p}$, deflexion $f$, general and local stability.

The second level is designing the system of elements, which are constructively connected and transfer the loading to each other. For example, in a beam system the structure of a beam knife edge depends on the type of a column and the structure of a column head depends on means of support.

And the third task level observes the operation of the building in general - all the elements of the first level together, which constitute the structure, and general factors influencing the operation of the first level elements, such as the structural design of the building, account for the special operation of the building, enveloping structures, building services, etc.

Costs for design. Let us investigate the question of additional costs for design, which will appear as a result of optimal design solution 
По разным оценкам стоимость проектных работ в совокупности затрат на строительство объекта из стальных конструкций может составлять от 3 до $8 \%$. Стоимость же материала несущих конструкций составляет до $25 \%$, изготовления — до $10 \%$ от стоимости возведения объекта. Исходя из этого, можно отметить, что дальнейшее увеличение затрат на проектирование, которое связано с построением полного дерева перебора вариантов и оценки каждого варианта проектного решения, должно компенсироваться стоимостью материала. За счет применения оптимальных проектных решений проектировщик должен добиться снижения расхода стали на несущие конструкции и соответственно снижение затрат на сталь.

Обозначим снижение стоимости материала $G_{m}$, а затраты на дополнительное проектирование $G_{n}$, тогда при условии $G_{n}<G_{m}$ мы получим экономически выгодную ситуацию для продолжения процесса поиска оптимального проектного решения. Пока затраты на проектирование конструкции будут меньше стоимости цели - минимизации расхода стали, дальнейшая работа по перебору вариантов проектного решения может продолжаться.

Как только $G_{m}$ становится равно $G_{n}$, то дальнейшая работа по проектированию строительной конструкции становится экономически нецелесообразной и построение дерева перебора вариантов проектного решения строительных стальных конструкций заканчивается. Т.е. при проектировании стальных конструкций есть смысл увеличивать затраты на разработку, оценку и сравнение вариантов, если есть возможность сэкономить больше затраченного. search, synthesis and estimation of the variants, account for multicriteriality, risks, uncertainty of the design task

Затраты на проектирование. Рассмотрим вопрос дополнительных затрат and other factors complicating the solution.

According to various opinions the cost for design operations may be from 3 to $8 \%$ of the whole cost of steel structures construction. Abd the cost of bearing structures material is up to $25 \%$, manufacturing - up to $10 \%$ of the building cost. Taking it into account we can note, that the further increase of costs for design, which is due to the full search tree creation and estimation of each variant, should be compensated by the cost of the material. The designer should reduce the steel consumption for the bearing structures and the expenses for steel by applying optimal design solutions.

Let us set the reduction of material cost as $G_{m}$ and the expenses for additional design as $G_{n}$ then, providing $G_{n}<G_{m}$ we will get economically advantageous situation to continue optimal design solution cost. While the expenses for design are less than the cost of the aim - the minimization of steel consumption, the further work on enumerating the design solution variants can continue.

When $G_{m}$ becomes equal to $G_{n}$, the further work on building structure design becomes economically unreasonable and the creation of the search tree stops. That means in case of steel structures design it is reasonable to increase development, estimation of the variants and comparing expenses, if there is a possibility to save more than spent.

Conclusion. In order to choose the optimal design solution it is necessary to study different variants of the solutions, 
Bывод. Для принятия оптимального проектного решения необходимо рассмотреть различные варианты решений, складываемые из переменных параметров, определяющих конструкцию. Для учета максимально возможного количества комбинаций в настоящей работе предлагается использовать метод построения дерева перебора — многоуровневой структуры строительной конструкции, синтезированной на основе структурного анализа конструкции строительного объекта. В дальнейшем полученные решения подвергаются оценке и выбирается лучшее - оптимальное по заданному критерию оптимальности. Для сокращения времени перебора вариантов предложена методика поиска проектного решения, основанная на ассоциативном методе. Идея заключается в том, что при разработке проекта проектировщик стремится получить выгодное совпадение проектных ситуаций использовать такие решения, узлы, элементы и конструкции, эффективность использования которых уже подтверждена и апробирована.

Таким образом, проектировщик прорабатывает значительное число комбинаций проектного решения, что позволяет надеяться на получение максимальной эффективности проектирования и повысить уровень надежности проектной организации [13].

\section{Библиографический список}

1. Нагинская B.C. Автоматизация архитектурно-строительного проектирования. М. : Стройиздат, 1979. 175 с.

2. Игнатов В.П., Игнатова Е.В. Эвристики данных в строительном проектировании // Вестник МГСУ. 2009. № 2. C. $226-229$.

3. Килина А.А., Паринов М.В., Чижов М.И. Архитектура системы поддерж- which are composed of variable parameters determining the structure. In order to account for maximal possible quantity of combinations in the give work we offer creating the search tree - a multilayered structure of a construction created basing on structural analisys of the construction. The obtained solutions are further estimated and the best is chosen - an optimal one according to the set optimality criterion. In order to reduce the enumeration time the method of design solution search basing on associative method is offered. The idea is that the designer tries to get the coincidence of design situations - to apply such solutions, nods, elements and structures, the efficiency of which has been already proved and tested.

That means the designer study a great number of design solution combinations, which allows expecting to get the maximal efficiency of design and increase the reliability level of an engineering company [13].

\section{References}

1. Naginskaya V.S. Avtomatizatsiya arkhitekturno-stroitel'nogo proektirovaniya [Automation of Architectural and Construction Design]. Moscow, Stroyizdat Publ., 1979, 175 p.

2. Ignatov V.P., Ignatova E.V. Evristiki dannykh $\mathrm{v}$ stroitel'nom proektirovanii [Data Heuristics in Construction Design]. Vestnik $M G S U$ [Proceedings of Moscow State University of Civil Engineering]. 2009, no. 2, pp. $226-229$.

3. Kilina A.A., Parinov M.V., Chizhov M.I. Arkhitektura sistemy podderzhki prinyatiya i kontrolya proektnykh resheniy [Architecture of Support System for Design Decision Making and Control]. Vestnik Voronezhskogo gosudarstvennogo tekhnicheskogo universiteta [Proceedings of Voronezh State Technical University]. 2011, vol. 7, no. 12-2, pp. 41- 44.

4. Agafonkina N.V., Karpov Yu.A., Stegantsev D.N. Model' odnokriterial'nogo prinyatiya resheniy $\mathrm{v}$ usloviyakh neopredel- 
ки принятия и контроля проектных решений // Вестник Воронежского государственного технического университета. 2011. Т. 7. № 12-2. С. 41- 44.

4. Агафонкина Н.В., Карпов Ю.А., Стеганщев Д.Н. Модель однокритериального принятия решений в условиях неопределенности // Вестник Воронежского государственного технического университета. 2009. Т. 5. № 6. C. $36-37$.

5. Veera P. Darji, Ravipudi V. Rao. Application of AHP/EVAMIX Method for Decision Making in the Industrial Environment // American Journal of Operations Research. 2013. No. 3. Pp. 542-569. Режим доступа: http:// www.scirp.org/journal/ajor/. Дата обращения: 03.06.2014.

6. Диксон Дж. Проектирование систем: Изобретательство, анализ и принятие решений / пер. с англ. М. : Мир, 1969. 440 с.

7. Хилл П. Наука и искусство проектирования. Методы проектирования, научное обоснование решений / пер. с англ. М. : Мир, 1973. 262 с.

8. Ботвинник М.M. О решении неточных переборных задач. М. : Сов. радио, 1979, $152 \mathrm{c.}$

9. Новикова А.Н. Опыт оптимизации проектного процесса на примере реального объекта в г. Казани // Известия КГАСУ. 2011. № 4 (18). C. $100-106$.

10. Ханина А.Б., Алехин В.Н. Внедрение экспертных систем в процессе проектирования строительных конструкций // Академический вестник УралНИИпроект РААСН. 2011. № 2. C. $82-85$.

11. Koch C., Buhl H. «Integrated Design Process» a Concept for Green Energy Engineering // Engineering. 2013. Vol. 5. No. 3. Pp. 292-298. Режим доступа: http://www.scirp. org/j ournal / P a per In formation . aspx?PaperID=28771\#.VA2GHvnV9cQ. Date of access: 03.06.2014. DOI: http:// dx.doi.org/10.4236/eng.2013.53039. ennosti [Model of One-Criteria Decision Making in the Conditions of Uncertainty]. Vestnik Voronezhskogo gosudarstvennogo tekhnicheskogo universiteta [Proceedings of Voronezh State Technical University]. 2009, vol. 5, no. 6, pp. $36-37$.

5. Veera P. Darji, Ravipudi V. Rao. Application of AHP/EVAMIX Method for Decision Making in the Industrial Environment. American Journal of Operations Research. 2013, no. 3, pp. 542 - 569. Available at: http:// www.scirp.org/journal/PaperInformation. aspx?PaperID=39747\#.VA18gPnV9cQ. Date of access: 03.06.2014. DOI: http://dx.doi. org/10.4236/ajor.2013.36053.

6. Dixon J.R. Design Engineering: Inventiveness, Analysis, and Decision Making. New York, McGraw-Hill, 1966, 354 p.

7. Hill P. Nauka i iskusstvo proektirovaniya. Metody proektirovaniya, nauchnoe obosnovanie resheniy [Design Science and Art. Design Methods, Scientific Rationale of Solutions]. Moscow, Mir Publ., 1973, 262 p.

8. Botvinnik M.M. O reshenii netochnykh perebornykh zadach [On Solving Unprecise Brute Tasks]. Moscow, Sovetskoe radio Publ., 1979, $152 \mathrm{p}$.

9. Novikova A.N. Opyt optimizatsii proektnogo protsessa na primere real'nogo ob"ekta v g. Kazani [Experience of Optimizing Design Process on the Example of Real Object in Kazan]. Izvestiya KGASU [Proceedings of Kazan State University of Architecture and Engineering]. 2011, no. 4 (18), pp. 100-106.

10. Khanina A.B., Alekhin V.N. Vnedrenie ekspertnykh sistem $\mathrm{v}$ protsesse proektirovaniya stroitel'nykh konstruktsiy [Expert Systems Implementation in the Process of Building Structures Design]. Akademicheskiy vestnik UralNIIproekt RAASN [Academic Proceedings of UralNIIproject of the Russian Academy of Architecture and Construction Sciences]. 2011, no. 2, pp. $82-85$.

11. Koch C., Buhl H. "Integrated Design Process" a Concept for Green Energy Engineering. Engineering. 2013, vol. 5, no. 3, pp. 292-298. Available at: http:// www.scirp.org/journal/PaperInformation. aspx?PaperID=28771\#.VA2GHvnV9cQ. Date of access: 03.06.2014. DOI: http://dx.doi. org/10.4236/eng.2013.53039. 
12. Гинзбург А.В., Василькин А.А. Постановка задачи оптимального проектирования стальных конструкций // Вестник МГСУ. 2014. № 6. С. 52-62.

13. Жавнеров П.Б., Гинзбург А.В. Повышение организационно-технологической надежности строительства за счет структурных мероприятий // Вестник МГСУ. 2013. № 3. С. 196-200.

Поступила в редакияию в июне 2014 2.

Об авторах : Волков Андрей Анатольевич - доктор технических наук, профессор, заведующий кафедрой информационных систем, технологий и автоматизации в строительстве, ректор, Московский государственный строительный университет (ФГБОУ ВПО «МГСУ»), 129337, г. Москва, Ярославское шоссе, д. 26, volkov@mgsu.ru;

Василькин Андрей Александрович - кандидат технических наук, доцент, доцент кафедры металлических конструкций, Московский государственный строительный университет (ФГБОУ ВПО «МГСУ»), 129337, г. Москва, Ярославское шоссе, д. 26, 8 (499) 183-3765, VasilkinAA@gic.mgsu.ru.

Для цити рования : Волков A.A., Василькин А.А. Развитие методологии поиска проектного решения при проектировании строительных металлоконструкций // Вестник МГСУ. 2014. № 9. С. 123-137.
12. Ginzburg A.V., Vasil'kin A.A. Postanovka zadachi optimal'nogo proektirovaniya stal'nykh konstruktsiy [Problem Statement for Optimal Design of Steel Structures]. Vestnik MGSU [Proceedings of Moscow State University of Civil Engineering]. 2014, no. 6, pp. 52-62.

13. Zhavnerov P.B., Ginzburg A.V. Povyshenie organizatsionno-tekhnologicheskoy nadezhnosti stroitel'stva za schet strukturnykh meropriyatiy [Using Structural Actions to Improve Organizational and Technological Reliability of Construction Activities]. Vestnik MGSU [Proceedings of Moscow State University of Civil Engineering]. 2013, no. 3, pp. 196-200.

\section{Received in June 2014}

About the authors: Volkov Andrey Anatol'evich - Doctor of Technical Sciences, Professor, Chair, Department of Information Systems, Technologies and Automation in Civil Engineering, Rector, Moscow State University of Civil Engineering (MGSU), 26 Yaroslavskoe shosse, Moscow, 129337; volkov@mgsu.ru;

Vasil'kin Andrey Aleksandrovich Candidate of Technical Sciences, Associate Professor, Department of Steel Construction, Moscow State University of Civil Engineering (MGSU), 26 Yaroslavskoe shosse, Moscow, 129337; + 7 (499) 183-3765; VasilkinAA@gic.mgsu.ru.

For citation: Volkov A.A., Vasil'kin A.A. Razvitie metodologii poiska proektnogo resheniya pri proektirovanii stroitel'nykh metallokonstruktsiy [Development of the Methodology of the Design Decision Searching in the Process of Structural Metalwork Design]. Vestnik $M G S U$ [Proceedings of Moscow State University of Civil Engineering]. 2014, no. 9, pp. $123-137$. 